\title{
Metanotal gland of the genus Eidmanacris (Grylloidea, Phalangopsidae): taxonomic importance
}

\author{
Rogilene Aparecida Prado \& Carmem S. Fontanetti
} Departamento de Biologia, Instituto de Biociências, Universidade Estadual Paulista (UNESP), Av. 24A, 1515, 13506-900 Rio Claro, SP,
Brasil. (raprado@ rc.unesp.br; fontanet@ @rc.unesp.br)

\begin{abstract}
The present study compares the metanotal gland through scanning electron microscopy in five species of Eidmanacris: E. corumbatai Garcia, 1998, E. alboannulata (Piza, 1960), E. dissimilis Desutter-Grandcolas, 1995, E. larvaeformis (Chopard, 1938) and Eidmanacris sp. The general external configuration of the gland was determined by the presence of two median projections with apical opening and a cluster of bristles just above these projections. Although there is a general pattern for this gland, each species has its own pattern, which can be defined mainly by the arrangement of the bristles and the position of the median projections. Our results suggest the taxonomical importance of these structures, which should be better analyzed when describing species of the genus Eidmanacris. In addition, while observing the reproductive behavior of these species, we concluded that the release of this gland secretion is important for the success of mating.
\end{abstract}

KEYWORDS. Mating, cricket, metanotal gland, reproductive behavior.

RESUMO. Glândula metanotal do gênero Eidmanacris (Grylloidea, Phalangopsidae): importância taxonômica. O presente trabalho compara a glândula metanotal de cinco espécies do gênero Eidmanacris por meio de microscopia eletrônica de varredura: $E$. corumbatai Garcia, 1998, E. alboannulata (Piza, 1960), E. dissimilis Desutter-Grandcolas, 1995, E. larvaeformis (Chopard, 1938) e Eidmanacris sp. A configuração externa da glândula foi determinada pela presença de duas projeções medianas que apresentam abertura em seu ápice e um grupo de cerdas abaixo destas projeções. Apesar de haver um padrão geral semelhante, a configuração da glândula é espécie-específica, que pode ser definida principalmente pela organização de cerdas e pela posição das projeções medianas. Nossos resultados sugerem a importância taxonômica desta estrutura, que deveria ser melhor analisada na descrição de espécies do gênero Eidmanacris. Pela observação do comportamento reprodutivo destas espécies, nós concluímos que a liberação da secreção desta glândula é importante para o sucesso reprodutivo.

PALAVRAS-CHAVE. Cópula, grilos, glândula metanotal, comportamento reprodutivo.

The genus Eidmanacris Chopard, 1956 comprises 12 species that are distributed at tropical latitudes of South America. The habitat of this genus is defined as straminicolous (forage in a leaf letter) and cavicolous (takes refuge in natural cavities), and they can be found mainly in subtropical forest (DESUTTER-GRANDCOLAS, 1995).

According to Mesa et al. (1998), the different species can be easily recognized according to the characters of the male genitalia, but they are difficult to identify through the female features.

In a proposal for a species-identification key, DESUTTER-GRANDCOLAS (1995) used, among several other characters, the presence and absence of metanotal gland. The presence of this gland has been occasionally reported by several authors while observing the mating behavior of certain species (LEROY, 1964; WALKER \& GURNEY, 1967; Ono et al., 1995; Mello \& JACOMINI, 1995).

WALKER \& GURNEY (1967) discussed the use of this gland as a taxonomical character for the genus Oecanthus Audinet-Serville, 1831 (Gryllidae); they proposed an identification key based on this structure for species that inhabit the United States of America. This gland is also known as Hancock's gland and is only present in the males of certain families. LOPES-ANDRADE \& Sperber (2001) observed this gland in preserved specimens of the genus Vanzoniella Mello e Reis, 1994 under scanning electron microscopy.

Several functions have been proposed for this gland. Since the female of some species removes the spermatophore as soon as she leaves the male, the secretion of this gland is probably important for the success in the transference of the spermatophore, entertaining the female while the sperm passes from the spermatophore to the receptacle. In this way, during copulation, the male exposes the gland by elevating the tegmen and the female climbs on the male feeding on the secretion. Another function of the gland would be to maintain the union of the couple until another spermatophore can be passed. It has also been attributed to this gland the guarantee of the specificity of the copulation, since the secretion would be species-specific and would avoid the response of females to heterospecific male courting (WALKER, 1963).

The aim of this study is to compare the metanotal gland of five species of the genus Eidmanacris Chopard, 1956 (Phalangopsidae).

\section{MATERIAL AND METHODS}

The thorax of adult males were extracted, including the pronotum, mesonotum and metanotum. These structures were fixed with Karnovsky solution and processed according to the technique for observation under the scanning electron microscopy.

The list of species used and the collection data follows: 1, Eidmanacris corumbatai Garcia, 1998, Brasil, 
São Paulo, Cerrado de Corumbataí, 30.X.1995, A. Mesa, P. Garcia \& C. Cherem col.; 2, E. alboannulata (Piza, 1960), Brasil, São Paulo, Itatiba, 18.X.1999, E. Zefa, R. A. Prado \& A. R. Miyoshi; Rio Claro, Horto Florestal, VI.1984, F. A. Mello col.; 3, E. dissimilis Desutter-Grandcolas, 1995, Brasil, Minas Gerais, Serra da Mantiqueira, Fazenda Saiqui - 20 Km, NO, Barreira do Piquete, 01.X.1983, A. Mesa \& D. Cella col.; 4, E. larvaeformis (Chopard, 1938), Brasil, São Paulo, Picinguaba, Pousada da Mila, Praia da Almada (2320'30"S - 44'51'59”W), 27.X.2000, A. Mesa \& P. Garcia col.; 5, Eidmanacris sp., Brasil, Goiás, Piripiri, 6 Km de Pirinópolis, 12-17.X.1997, A. Mesa \& P. Garcia col.; idem 17.VIII.1997, A. Mesa \& E. Zefa col.

\section{RESULTS}

The analyses of the metanotal gland of the genus Eidmanacris evidenced the presence of a general basic pattern among the species which comprises: 1) the presence of two median projections; and 2) a cluster of bristles that are located immediately ahead of these projections (figs. 1-5). The particular arrangement of these structures is peculiar for each studied species.

The median projections might appear in close proximity to each other, as observed in E. dissimilis (figs.
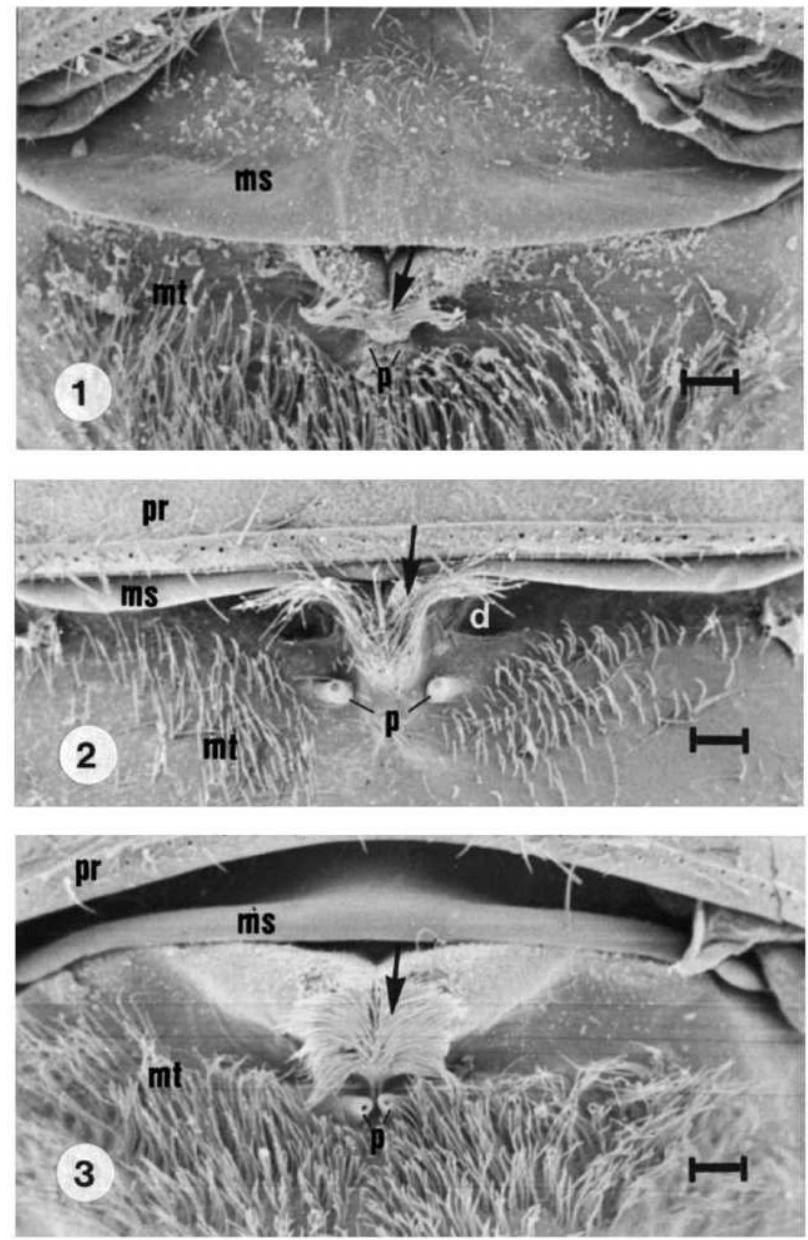

1, 6), or more separated as in E. larvaeformis (figs. 2, 8) while in Eidmanacris sp. these projections are hardly evident (figs. 5, 9).

The cluster of bristles also appears different among the species. In E. dissimilis and E. larvaeformis there are few bristles, however, they are long and originate from the median region in a lateral direction (arrows in figs. 1, 2 ). On the other hand, in E. alboannulata, the bristles are shorter and form two clusters that are clearly separated at the median region (arrow in figs. 4,10 ). In E. corumbatai and $E$. sp. the bristles form a single cluster (arrow in figs. 3, 5, 7, 9). In E. corumbatai the bristles are longer and anteriorly directioned (fig. 7). Eidmanacris sp. showed the most differentiated bristles arrangement among the species studied; the bristles originate from a single structure that is projected from the metanotum and towards posteriorly (arrow in figs. 5, 9). In this species, the bristles cover most part of the median projections (fig. 9).

The median projections had an opening at the top, which, depending on the preparation, can be covered by a secretion (arrowhead on fig. 12, 14) or not (figs. 11, 13). The observations suggest that this opening is the local through where the secretion is liberated by these glands.

Besides the configuration of the glandular features, we observed that the species also differ in other aspects
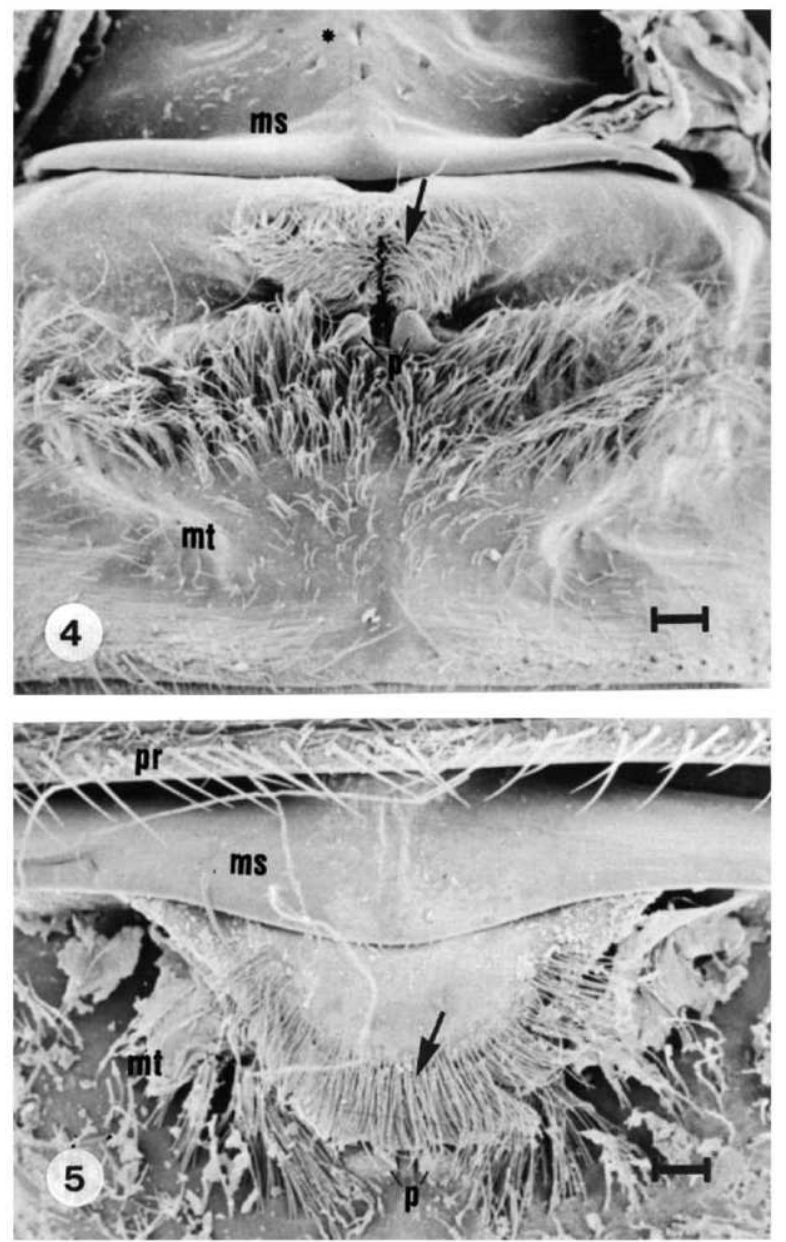

Figs. 1-5. Thoracic segments of Eidmanacris. 1, E. dissimilis; 2, E. larvaeformis; 3, E. corumbatai; 4, E. alboannulata; 5, Eidmanacris sp. (d, depression; ms, mesonotum; mt, metanotum; p, projections; pr, pronotum; arrows, cluster of bristles; *, a series of orificies). Bars, $100 \mu \mathrm{m}$. 

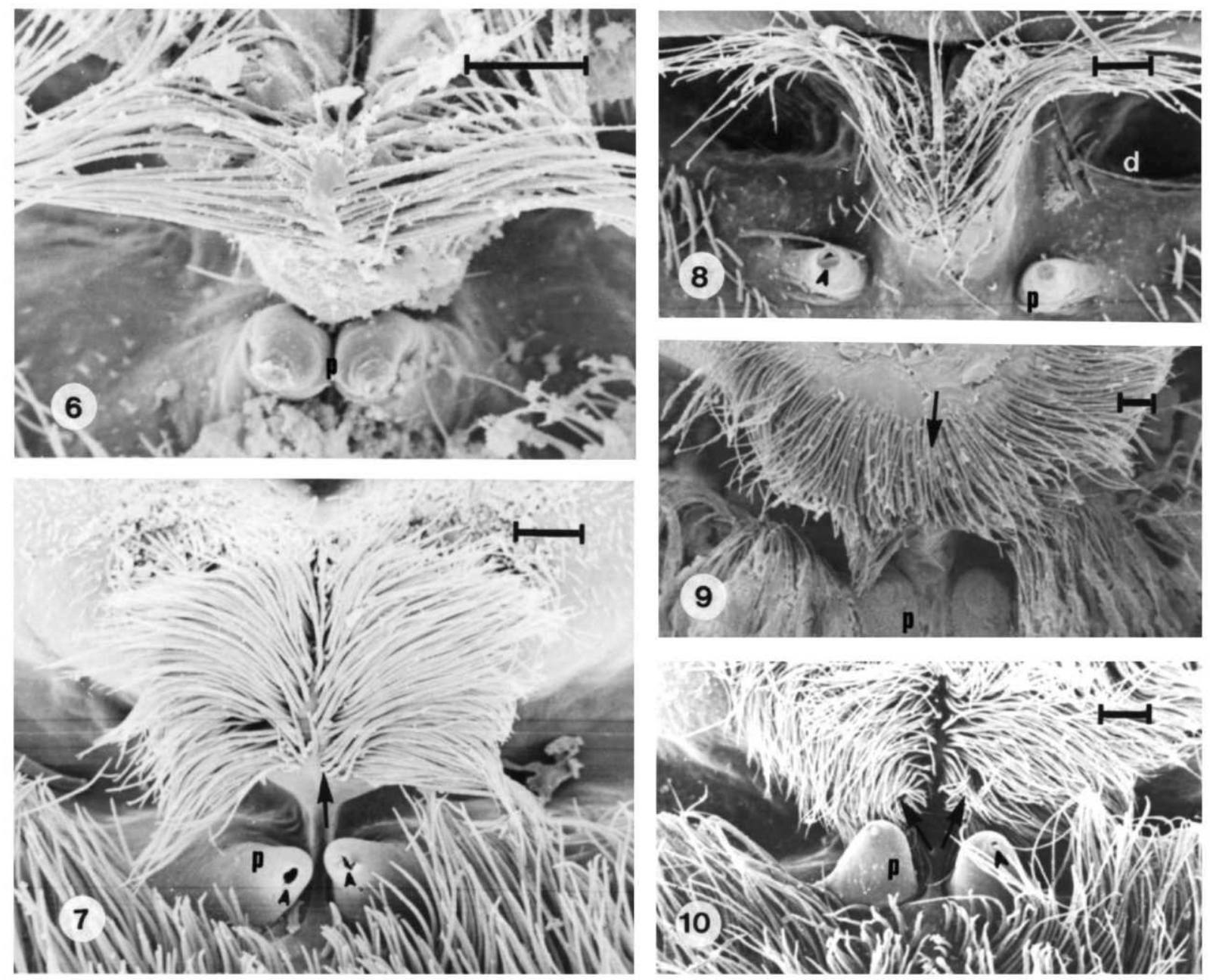

Figs. 6-10. Metanotal gland of Eidmanacris. 6, E. dissimilis; 7, E. corumbatai; 8, E. larvaeformis; 9, Eidmanacris sp.; 10, E. alboannulata (d, depression; p, projections; arrows, cluster of bristles; arrowhead, apical opened on the projections). Bars, 50 $\mu \mathrm{m}$.

of this region, such as the mesonotum and the metanotum shape.

Both E. dissimilis (fig. 1) and E. alboannulata (fig. 4) present a wide mesonotum; however, in E. dissimilis, this structure presents bristles at its median region, while in E. alboannulata the median region of the mesonotum shows a series of orifices (* in fig. 4) that were not observed in any other species. On the other hand, in $E$. larvaeformis (fig. 2), E. corumbatai (fig. 3) and Eidmanacris sp. (fig. 5), the mesonotum is narrow and the most part of it is covered by the pronotum.

The metanotum in E. dissimilis, E. corumbatai and E. alboannulata appears densely covered by bristles (figs. 1, 3, 4, respectively), while in E. larvaeformis and Eidmanacris sp. (figs. 2, 5), the bristles appear in fewer numbers, next to the median projections. Two depressions were observed immediately above the median projections in E. larvaeformis (figs. 2, 8), which confer an unique appearance to the metanotum of this species.

\section{DISCUSSION}

The metanotal gland was described by HANCOCK (1905) in Allonemobius fasciatus fasciatus (De Geer 1773) [=Oecanthus fasciatus]; it was simply referred as a "glandular cavity" by which the male secrets a substance that is absorbed by the female during copulation. Other authors also entitled this gland with the same name (WALKER \& GURNEY, 1967) or as "metathoracic crevices" (Leroy, 1964). Although there is little information concerning this gland, its importance in the success of the copulation in crickets that posses it is undeniable.

According to our results, although a similar general pattern is evident in all species studied, the configuration of the metanotal gland is species-specific and could be used in the description of species of the genus Eidmanacris. In addition, the configuration of the mesonotum associated to the observations of the metanotum could also help to differentiate these species since our observation showed that there is not intraspecific variation.

Отте (1992) suggested that the metanotal gland is probably ancient and might be present in species that stridulate as well as in species that lost the ability to signalize by sound. Nevertheless there is no evidence suggesting tendency for a more developed gland in the non-stridulating species.

DesutTer-Grandcolas (1995) used this gland to establish a discussion concerning the phylogeny of the genus Eidmanacris. The author commented that 

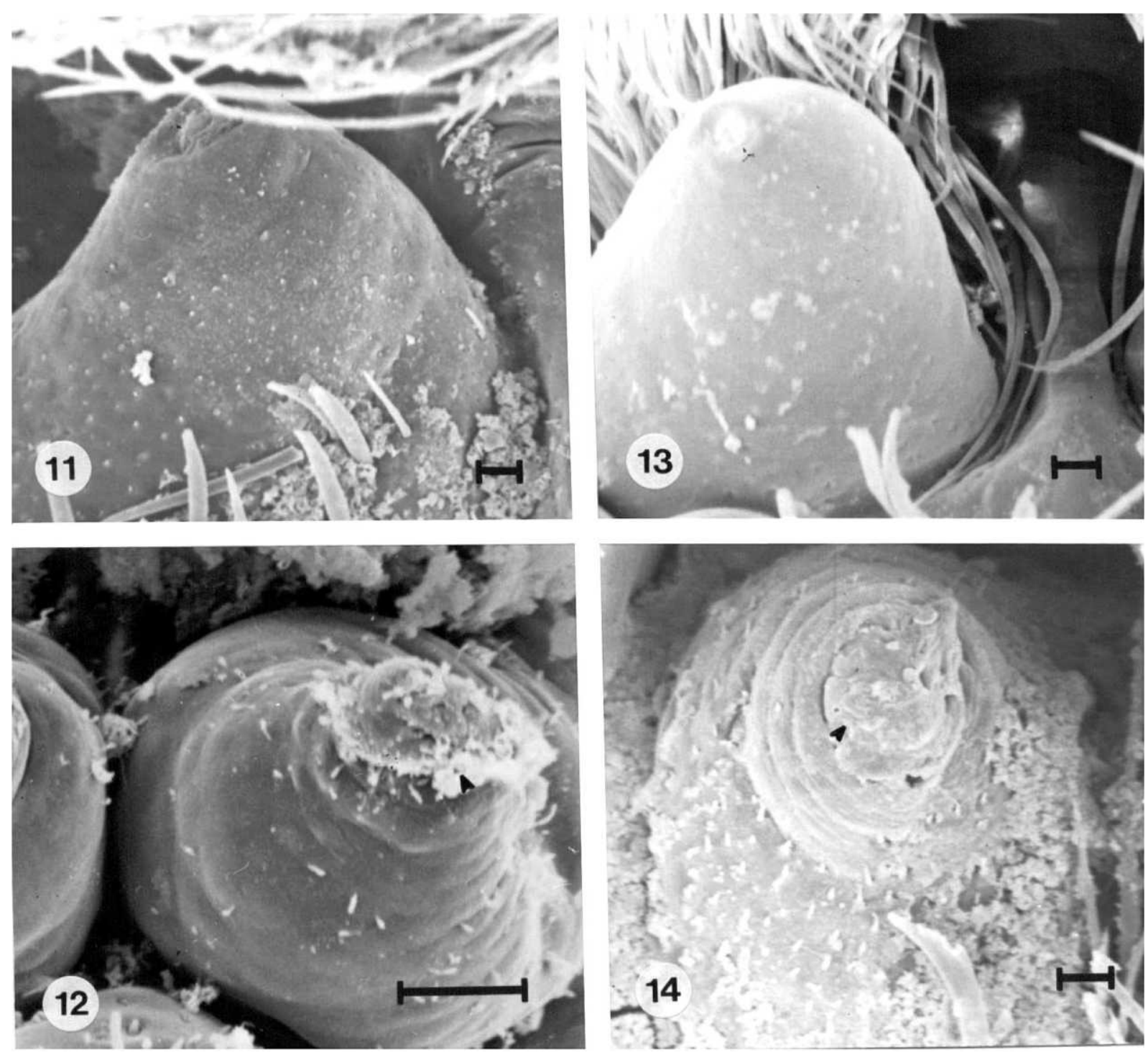

Figs. 11-14. Projections of metanotal gland of Eidmanacris. 11, E. corumbatai; 12, E. dissimilis; 13, E. alboannulata; 14, Eidmanacris sp. $($ arrowhead $=$ secretion $)$. Bars, $10 \mu \mathrm{m}$.

the formation of a median projection (and therefore a double row of bristles) originating from the anterior edge of the metanotum and the structure of the cylindrical vertical formations (with opened top) are apomorphic features in the genus Eidmanacris that, together with other characters, support a monophyletic origin for this genus.

In spite of the functional and morphological significance of this gland for taxonomical and evolutionary issues, little attention has been given to them. The reports of this gland in scientific literature do not clarify its morphology or the nature of its secretion. Most of the reports on this gland originates from behavioral analyses made in some groups (Walker, 1963; Leroy, 1964; Ono et al., 1995; Mello \& JACOMINI, 1995).

Acknowledgments. To Edison Zefa and Akio Myioshi for their help during collection of the specimens and Mônika Iamonte for technical support.

\section{REFERENCES}

Desutter-Grandcolas, L. 1995. Le genre Eidmanacris Chopard (Orthoptera: Grylloidea, Phalangopsidae, Luzarinae): habitat, repartition et espéces nouvelles. Bulletin du Museum National d'Historie Naturelle,16(2-4):453474

HANCOCK, J. J. 1905. The habits of the striped meadow cricket (Oecanthus fasciatus Fitch). The American Naturalist, 39(457): $1-11$.

Leroy, Y. 1964. Les caracteres et le comportement acoustique des males d'Homoeogryllus reticulates Fabricius (Orth. Ensiferes Phalangopsidae). Bulletin de la Société Entomologique, 69:7-14.

Lopes-Andrade, C. \& Sperber, C. F. 2001. Evaluation of the presence of glandular strucutures in preserved crickets (Orthoptera, Grylloidea, Phalangopsidae) using a comparative scanning electron microscopy technique. Journal of Orthoptera Research, 10(2):343-345.

Mello, F. A. G. \& Jacomini, L. 1995. Sobre a utilização de dados da comunicação acústica e outros aspectos do comportamento sexual na sistemática e história natural de grilos. Anais de Etologia, 13:103-115. 
Mesa, A.; Sperber, C. F. \& Garcia, P. C. 1998. Two new species of the cricket genus Eidmanacris and a new combination name for a third species (Orthoptera: Grylloidea: Phalangopsidae). Transactions of the American Entomological Society, 124(1):43-61.

Ono, T.; Hayakawa, F.; Matsuura, Y.; Shiraishi, M.; Yasui, H.; NAKAMURA, T. \& ARAKAWA, M. 1995. Reproductive biology and function of multiple mating in the mating system of a tree cricket, Truljalia hibinonis (Orthoptera: Podoscritinae). Journal of Insect Behavior, 8(6):813-824.
Oтте, D. 1992. Evolution of crickets songs. Journal of Orthoptera Research, 1:25-49.

WALKER, T. J. 1963. The taxonomy and calling songs of United States tree crickets (Orthoptera: Gryllidae: Oecanthidae). II. The nigricornis group of the genus Oecanthus. Annals of the Entomological Society of America, 56(6):771-789.

Walker, T. J. \& Gurney, A. B. 1967. The metanotal gland as a taxonomic character in Oecanthus of the United States (Orthoptera: Gryllidae). Proceedings of the Entomology Society of the Washington, 69(2):157-161.

Recebido em julho de 2004. Aceito em janeiro de 2005. ISSN 0073-4721

Artigo disponível em: www.scielo.br/isz 